\title{
Volunteering, the market, and neoliberalism
}

\author{
Jon Dean* \\ Sheffield Hallam University
}

\begin{abstract}
This paper builds on recent literature which has examined how trends in volunteering, at the organisational, operational and policy levels, may be negatively affecting the nature of volunteering itself. Within the hegemony of neoliberalism, theorists and researchers have argued that greater market individualism and flexible capitalism can ultimately damage kinship, collectivism, altruistic tendencies, and social compassion. While participating in volunteering clearly benefits the individual volunteer as well as the person or community they are helping, it is argued that a social order which prioritises benefit to the individual over benefit to the collective may cause potential long-term damage to the act of volunteering. Drawing on the work of theorists from a range of disciplines, this paper aims to frame current developments in volunteering within the wider theoretical critique of marketisation and neoliberalism, particularly those critiques which focus on the damage to or decline of community life.
\end{abstract}

Keywords: community, market, neoliberalism, voluntary sector, volunteering.

\section{Introduction}

For thirty years we have made a virtue out of the pursuit of material self-interest: indeed, this very pursuit now constitutes whatever remains of our collective purpose. (Judt, 2010: 1)

This paper seeks to build on recent literature (for example, Dean, 2014a; Holdsworth and Brewis, 2013; Hustinx and Meijs, 2011) which has examined how trends in volunteering and the voluntary sector, traditionally associated with market neoliberalism, may be negatively affecting the nature of voluntary commitment itself. Neoliberalism, a political-economic doctrine which puts impersonal market reasoning at the centre of public and private decision-making (see Hayek, 1944), has become the hegemonic Western paradigm (Davies, 2014; Hall, 2011) for not only economic management, but also political and, as this paper will argue, social functioning. Writers such as Sennett (1998: 148) have argued that as communities fracture, due to the social and economic pressures of neoliberal capitalism, greater market individualism delivers societies 'which provide human beings no deep reasons to care about one another.' Clearly, if such a trend exists there is the potential for long-term damage 
to the act of volunteering, an act which at its very heart is about providing for each other's needs.

One such example is the trend toward volunteering to improve one's own skills, in order to better compete in the jobs market, rather than to fulfil a social need. A move to more instrumentally-motivated volunteering has changed volunteer-involving organisations' recruitment strategies, which focus on the benefit volunteering can bring to an individual (such as increasing their economic or human capital) over the potential altruistic benefits that arise from donating one's time to help others (for an overview see Dean, 2014a). Volunteering is also used as a tool of competition, for example within universities. Universities see their offer of volunteering as an area where they can develop a market advantage, recruiting students with the promise of wider and better experiences in order to aid their future employment (Holdsworth and Brewis, 2013). The volunteering recruiters interviewed in Dean (2014a) talk of volunteering as a product to be 'sold' to young people, which leads to young volunteers taking on the mindset of the consumer. While this raises questions of practicalities around volunteer commitment, it also creates wider moral and ethical questions, impacting both social life and social policy.

The purpose of this paper is to outline these existing findings and locate them within wider theoretical discussions about the inherent consequences of the individualisation and marketisation of elements of everyday community life. This is done through reversing the traditional structure of an academic paper. First, an overview of recent findings from researchers studying volunteering is presented, focusing on trends apparent in volunteering policy and practice which confirm the argument that volunteering and volunteers are moving towards a more marketised approach and attitude. The second section then explores the theoretical ideas which may explain such trends and developments in a wider context. While, as will be shown, some voluntary sector and volunteering researchers have applied theoretical critiques of neoliberalism in their work, recent comments by Rochester (2015) (echoing the author's own view), have criticised volunteering research for not explicitly asking whether volunteering and the voluntary sector are compatible with a neoliberal market society. By bringing an original range of writers to our analysis of volunteering this paper presents cautionary tales in response to Rochester's question, and asks us to consider another one: what damage is being done by the marketisation of volunteering?

\section{Volunteering and the market: existing evidence}

Recently, there has been a spate of critical literature examining changes in the voluntary sector and within volunteering. Dean (2014a) draws on qualitative research with volunteer recruiters and practitioners to argue that the very design of certain volunteer programmes and policies, and how these policies were operationalised by staff, actively promoted instrumental motivations in young volunteers: as one interviewee said, 'it's turning them into mercenaries!' Similarly, Holdsworth and Brewis (2013), in their analysis of the role volunteering plays within universities, see a move from volunteering as extra-curricular to volunteering as co-curricular. Such a move sees volunteering both as a service universities must invest in in order to differentiate themselves from their competition, but also as a way of helping students find employment after graduation, part of the key information set (KIS) data on which universities are now measured and judged. Of course, universities see the altruistic value in encouraging and enabling their students to volunteer, but the researchers' interviewees report altruism as a soft target, a naturally emanating off-shoot (and not a 
core aim) of their volunteering policy - unlike developing employability or forging links with local organisations which are central aims.

Similarly Handy et al's (2010) cross-national study of the motivations of student volunteers found that those students in countries with neoliberal welfare regimes (such as the United States, United Kingdom and Canada) were more likely to give their time in order to build their résumé, and that volunteers with such motivations committed less time to volunteering. In Dean (2014b) elite schools concertedly cultivated a volunteering habitus among their students, encouraging them to 'game' the local volunteering networks for the reward of furnishing their CVs with experiences. Wilson and Musick (2000: 167) caution that 'there are justifiable fears that attaching rewards to altruism will undermine motivation and distort values', and present evidence suggesting that the benefits of volunteering often come through intrinsic motivation (to complete the voluntary act) rather than extrinsic motivation (to gain an identified benefit). While instrumental and individualised motivations fit neoliberal attitudes, they undercut the benefits which policy practitioners and various stakeholders hope volunteering can bring.

Similar trends are apparent in the work of scholars looking at the voluntary sector more widely: Angela Eikenberry and Patricia Nickel (2009; 2013; Eikenberry, 2009) extensively analyse the negative consequences of nonprofit organisations adopting the language and practices of the private sector. Rochester (2013), building on a lifetime's involvement with volunteering, asks if the voluntary sector is losing its soul through increased contracting, service delivery, and the adoption of corporate tendencies. Similarly, the activist National Coalition for Independent Action (NCIA) posits that through contracting and commissioning the very nature of the voluntary sector is being undermined. The statutory sector's adherence to neoliberal ideology, the NCIA (2015) argues in a recent report, has meant that the voluntary sector has become another cog in the privatisation of public services, which has led to the defunding of established community groups, altering the nature of the voluntary spirit. 'Dominant ideas about volunteering have moved away from self-help, community development and campaigning to the "workplace model" that sees volunteers as unpaid workers' (NCIA, 2015: 9), a position we somewhat see reflected in the recent studies examined above.

Ultimately, following Edwards' (2008) lead, Eikenberry reasons that such changes lead nonprofit organisations, and their paid and unpaid workers, to depoliticise, focusing their efforts on symptoms rather than root causes, and tackling short-term and individual issues, as opposed to campaigning for underlying change to tackle structural inequalities. Similar findings in Brooks' (2007) research show that youth volunteering which is merely 'participatory' is largely ineffectual as a means of educating for active citizenship; critical engagement with social relations are more important. Yet even where instances of such engagement were found the motivation for participation was dominated by CV building and UCAS form enhancement.

Writing in 2010, the historian Tony Judt (2010: 130) offers the following analysis:

In an age where young people are encouraged to maximise self-interest and selfadvancement, the grounds for altruism or even good behaviour become obscured. Short of reverting to religious authority... what can furnish a younger generation with a sense of purpose beyond its own short-term advantage?

Social and political movements and campaigns, such as Occupy, Podemos in Spain, Syriza in Greece, the Umbrella movement in Hong Kong, and the independence referendum in Scotland have managed to energise certain strata of young people, but these may just be fragmented responses to a temporary crisis. The long-term trend of individualisation is considered by Hustinx (2000: 57) as 'the most dangerous threat to volunteering, eroding what solidarity still remains among citizens.' With much of the 
solidity of social and economic life removed, young people have to construct fractured and flexible identities and preferences (Giddens, 1991), which, as Bauman (2007: 4-5) cautions, makes people more likely to 'abandon commitments and loyalties without regret', particularly at times of heightened precarity.

A society where people are more likely (or encouraged) to abandon commitments and loyalties is of huge significance to volunteering and the voluntary sector. This paper now looks through a wider angle, to explain the evidence about volunteering outlined above through theoretical contributions which have explored the impact of neoliberalism and marketisation on community and social life more generally.

\section{Volunteering and the market: theoretical perspectives}

This next section of the paper serves to provide a wider theoretical and sociological context for the existing findings outlined above. In the author's view, the established academic literature on volunteering often shies away from including wider theoretical ideas and critiques. This position is neatly encapsulated by Rochester (2015), who argues that the field of voluntary sector studies requires a 'more critical approach to discussing the role and significance of voluntary organisations and volunteering in our society', a need to analyse 'the infiltration of the culture and behaviours of the market into the non-market parts of our society', and to ask whether the values of volunteering are compatible with a market society. This paper seeks to contribute to this burgeoning body of work. It will do this by first providing a brief review of the neoliberalisation literature, before moving on to argue that the findings from the recent studies of volunteering presented above constitute a worrying trend because the findings replicate the wider social 'hollowing out' witnessed elsewhere.

\section{The neoliberal mindset}

Neo-liberalism is in crisis. But it keeps driving on. However, in ambition, depth, degree of break with the past, variety of sites being colonized, impact on common sense and everyday behaviour, restructuring of the social architecture, neoliberalism does constitute a hegemonic project. Today, popular thinking and the systems of calculation in daily life offer very little friction to the passage of its ideas. (Hall, 2011: 728)

In his internationally bestselling book What Money Can't Buy: The Moral Limits of Markets, the philosopher Michael Sandel (2013: 64-5) recounts the story of a group of Israeli nurseries, whose staff, annoyed at constantly having to stay after work because parents were late picking up their children, chose to implement a system of fines. Parents would have to pay $\$ 1$ every minute they were late. The nursery staff did not want the money; they wanted parents to arrive on time, so they could go home, perhaps to their own children. The effect of the new dollar-a-minute fines system? More parents were late. The norms of the social relationship, where the parents felt guilty for the nursery staff having to stay late, were removed, and many parents were willing to use their economic capital to cancel out the social negativity of their tardiness. The introduction of market values had fundamentally altered the human relationship between parents and nursery staff: parents took advantage of their option to buy themselves out of their social contract.

Many authors (for example, Davies, 2014a; Hall, 2011; Harvey, 2011; Kunkel, 2014; Sandel, 2013; Stiglitz, 2013; Wilkinson and Picket, 2010), have considered with renewed vigour the impact of neoliberalism and inequality on ordinary lives since the financial crisis of 2008. To write of market forces or marketisation as if they were some 
corporate behemoth seeking to remove the soul from human life lacks both nuance and academic rigour. Yet as the above examples from studies of volunteering show, there are processes occurring at various levels of policy and social behaviour which have hegemonised, in Hall's term, market reasoning into social life, and that these processes are either potentially, partially, or wholly damaging. Kunkel (2014: 31-2) sees this as the 'penetration of capitalist relations into all sectors of the economy, the mobilisation of various "latent" sources of labor power...commodifying the most intimate of formerly uncommodified practices.' This commodification of noncommodities is problematic, as there are significant differences between capital/economic goods and social goods. The very nature of capital is not to provide high social returns, but high private returns (Harvey, 2011), seen in the roots of the 2008 financial crisis which prioritised elite short-term profit at the expense of economic stability, social stability and equality (Kunkel, 2014: 43). This assertion mirrors the much-discussed recent conclusions of economist Thomas Piketty (2014) in his opus Capital in the Twenty-First Century, with its central thesis of $r>g$, where $r$ (the rate of return on capital, benefitting private investments) always ultimately outstrips $g$ (the rate of economic growth, benefitting wider society).

Capitalism is better understood as designating a society that subordinates all processes - notably the metabolism between humanity and nature, the production and distribution of goods and services, the function and composition of government, and, of course, market exchange - to the private accumulation of capital. (Kunkel, 2014: 141, emphasis added)

The impact, it is argued, is not just on investment, trade, services, and financial transactions, but, as Kunkel puts it above, the metabolism between humanity and nature, the very relationship and interconnectedness between people and their social lives. Boris Groys (2010) argues that communism was not principally about the common ownership of the means of production and the equal distribution of resources, but in seeking to wage war with Western capitalism, communism sought to value politics ('the medium of language') above economics ('the medium of money'). This reads closely with William Davies' (2014a: 3) analysis of neoliberalism as 'an attempt to replace political judgement with economic evaluation', subordinating freedom and sovereignty to the market, turning 'all would-be signifiers into mere price signals' (Kunkel, 2014: 161). Groys, similarly to Furedi's (2004) study of universities, sees this in his analysis of modern art, where, in his view, art's capacity for transcendent meaning has been usurped by a 'mute' subservience to the market. Davies (2014b, emphasis added) sees neoliberalism not as a philosophy which seeks to replace the state or democracy with the market, but that one where 'processes traditionally left in the realm of politics must now be reconfigured in calculative, economically rational terms.' Davies uses examples such as opera, providing social care for the elderly, and undertaking opaque academic research as activities which one (or the state) is still free to undertake, but they must be both explained in the language of economics, and have economic rationales: utilitarianism based on audit.

Davies (2014b) goes on to argue that instigating unhappiness is one of neoliberalism's most important tools. If true this has significant consequences for social life, and, by extension, volunteering, because as Douthwaite (1996: 362) asserts 'humans are only fully human when we are involved with each other, and the majority of us find happiness most easily through collective achievement.' Writing in analysis of anthropologist David Graeber's work, Kunkel (2014: 113) reasons that 'people act as communists not only towards friends and family but often towards guests, neighbours, and strangers.' This builds on Graeber's (2013) Kropotkin-esque statement about mutual aid: social relations are not built on a marketised 'give and take' calculation 
that someone else will do something for you in return, but that they would. Similarly, the Marxist utopia envisioned by Žižek (2010) sees people coming by goods and services not through market exchange, but through a direct social exchange of activities. Such communal activity has been found in the 'communist utopia' of Marinaleda in Spain, where the village's population come together every few Sundays for a day of reciprocal volunteering (Hancox, 2013). But, the writers discussed here argue, envisioning this base level of civic trust has become more difficult because neoliberalism has damaged people's social ability, and tempered their psychological rationale, to care about each other. The very notion of altruistic volunteering, giving one's time without an economic rationale, has been challenged. And, as the next section will now posit, when looked at in tandem the tenets of neoliberalism briefly outlined here and the trends identified in volunteering previously potentially lead us to worrying conclusions about the role, nature, and extent of volunteering in the future.

\section{Marketising community life}

The literature on individualism has often seen the growth and extension of capitalism into more aspects of everyday life as part of the never-sated appetite of the market, a fragmented 'liquid modernity' of isolated and morally indifferent individual consumers, cut adrift by the pure exchange model of consumer-commodity relations (Bauman, 2001; 2007; Bauman and Bordoni, 2014). In The Corrosion of Character (1998: 145), Richard Sennett sees hope in the strength of the IBM workers he interviews, because 'they took responsibility for their failures and insufficiencies together', understanding that responsibility was a communal and inter-dependent effort, not merely a personal and isolated game of reward and blame. But he sees this as rare in modern capitalism, where character is diminished: 'there is history, but no shared narrative of difficulty, and no shared fate' (Sennett, 1998: 147). The growth of individualism, as coined by de Tocqueville (1862) in Democracy in America, which strengthened the bonds of trust in kinship at the expense of bridging with strangers, has led to fractured communities, of isolated persons and families. In these we bemoan the loss of the 'greater moral resources' (Delanty, 2000: 116) of gemeinschaft, a unity based on personal and intimate social relations of local community life, to gesellschaft ,a social order centred on impersonal and contractual relations of a more calculating kind (Tönnies, 1955).

This dependence on others for survival was witnessed by Kropotkin (1914) among the volunteers of the miners' associations of the Rhonda Valley who rescued those trapped underground. Kropotkin asked why these men of impoverished rural communities were more likely to volunteer to come to the aid of others than those who witness crime and distress in big cities. The answer, he wrote, was in the inherited instincts and education of these communities (Kropotkin, 1914: 275-8), akin to that developed by the animal communities he observed in the wild. While they do volunteer in a formalised and organised society, they do it because of the generations of human psychology and emotional involvement they have with those who they are saving, evidenced by the accounts given by the volunteers as to why they choose to risk their lives for others, rather than because they have been recruited to volunteer or to gain a skill or to boost their CV. This contrasts with the blasé nature of city life, analysed by Georg Simmel (2011), who saw that the monetisation of time in urban areas could lead to instrumental attitudes toward other people.

Sennett (1998: 148) sees this individualism, the flexible capitalism which is central to the neoliberal agenda, as a prime foundation for societies 'which provide human beings no deep reasons to care about one another', eliminating their legitimacy. As the 'we' of community has often turned from a source of mutual respect, responsibility and pro-active behaviour, into a darker, defensive and protectionist reaction (Sennett, 
1998: 137-8; see also Lawler, 2008: 122-5; 2002), volunteering and altruism have increasingly followed the market's lead. Nickel and Eikenberry (2009) write that through the marketisation of charitable acts, philanthropy and the drive for social betterment have come to be defined as elements which operate in the service of consumption, which in turn breeds more consumption, also witnessed in the research into volunteering of Nina Eliasoph (2011).

The volunteering industry, and the volunteering policies it enacts, as governments seek to 'hyper-actively' (Kendall, 2005) utilise volunteering for state purposes (Sheard, 1995), is trapped and forced to operate within these boundaries; young people are encouraged to consume volunteering as without it, they cannot move up or move on (Dean, 2014a). Just as the state, in order to solve its own crises, encourages (or forces) local communities to run their own services unwaged (Dowling and Harvie, 2014), volunteering becomes subsumed into the logic of individualisation in advanced economies (Hustinx, 2001; Hustinx and Lammertyn, 2003). As a result unwaged work is imposed, either through welfare sanctions or through the 'Hobson's choice' alternative of the removal of funding, rather than truly volunteered. Such developments are the subject of challenge in the new Keep Volunteering Voluntary campaign (www.kvv.org.uk).

\section{Conclusions}

A market society is a way of life in which market values seep into every aspect of human endeavour. It's a place where social relations are made over in the image of the market. (Sandel, 2013: 10-1)

The critique presented in this paper could easily be criticised as being overly negative. Volunteering, in various forms, has existed for centuries across innumerable contexts and will continue to do so for centuries more, with volunteers motivated to give their time for a complex variety of reasons. As the Community Life Survey findings indicate (Cabinet Office, 2014: 8), the rate of formal volunteering in the UK has stayed remarkably stable this century, despite state funding and volunteering's profile fluctuating. Yet those working on the front line of voluntary action see subtle changes in the nature and principles of volunteering, especially around enforced volunteering due to welfare sanctions and job substitution (Curtis, 2015). These issues and those outlined at the start of this paper (alongside major social developments such as demographic changes [see the Commission on the Voluntary Sector \& Ageing, www.voluntarysectorageing.org]), pose serious challenges to volunteering in the UK, as we know that, for instance, enforced volunteering can deter future involvement (Planty et al., 2006; Warburton and Smith, 2003).

The recent findings about volunteering presented here are viewed through a critique of neoliberalism's impact on society. This echoes similar critiques of the impact market capitalism has had on other ordinary processes and actions of everyday life, including Furedi (2004) on the usurping of art and knowledge, and Crary (2013), who argues that as sleep is an affront to capitalism it is being undermined. The old-fashioned ideal of the altruistic volunteer is such an affront. And yet, through the value it adds to society, particularly in terms of the economic value of unpaid caring responsibilities, volunteering fills gaps that the market cannot, and provides services the state is unwilling to provide or unable to afford. As Rochester (2013: 201) has starkly put it, 'voluntary action...has been pressed into the service of the state and has been radically changed in the process.' 
The technological developments of globalisation have enabled engaged volunteers and activists to communicate across borders and oceans, but while they can create global communities of interest, this does not translate into communities of space. And it is communities of space in which decisions get made, politicians get elected, services get cut, and volunteers help those in need: as Judt (2010: 121) states, 'real-time access to likeminded fellows half a world away is no substitute.' Yet the technologies of capitalism, such as the digitisation of money, social security, and communication, in their ever-consuming aim to eliminate waste and encourage efficiency, reduce community interactions and the everyday rituals of exchange which 'contributed mightily to a greater sense of citizenship' (Judt, 2010: 121) and compassion. The 'liberating experience' of public action (Hirschman, 1982) is subsumed by the calculative attitude toward social life (Furlong and Cartmel, 2007: 5) required for security in the risk society (Beck, 1992). Panacea policies such as those outlined earlier aimed at encouraging young people to volunteer or, on a wider scale, the Big Society, have failed to fill the gaps in social reproduction and cohesion, which are instead widening.

This paper has aimed to make several additions to our understanding of volunteering. By bringing together in a short literature review the related findings of several recent research projects it can be reaffirmed that volunteering is changing. By then presenting an overview of a range of theoretical critiques of neoliberalism and trends within market societies, and by bringing a range of original voices into the academic literature on volunteering, we can see how this analysis explains these trends in volunteering, and, in conclusion, provides us with critical questions and cautionary tales about the significant impacts both on volunteering and wider society that are arising as a result. Ultimately we can conclude that we should be wary of any further attempts to reframe voluntary action for the state's or the market's needs. As Dowling and Harvie (2014: 882) conclude:

capital's lifeblood is unpaid work, and the Big Society as political economy is an attempt is extend the realm of unpaid work that can be appropriated.

This appropriation, of those human activities which seek to reproduce the caring social relationships that make our lives liveable, potentially makes all our futures more precarious.

\section{Acknowledgements}

Thanks must go to the organisers and participants of The Third Sector, the State and the Market: Challenges and Opportunities in an Era of Austerity research symposium in October 2014, to Will Eadson for his editorial time and critical feedback, and to Angela Eikenberry for supporting earlier developments in this work.

* Correspondence Address: Jon Dean, Department of Psychology, Sociology and Politics, Heart of the Campus Building, Collegiate Crescent, Sheffield, S10 2BQ. Email: j.dean@shu.ac.uk 


\section{References}

Bauman, Z. (2001) The Individualized Society. Cambridge: Polity.

Bauman, Z. (2007) Consuming Life. Cambridge: Polity Press.

Bauman, Z. and Bordini, C. (2014) State of Crisis. Cambridge: Polity Press.

Beck, U. (1992) Risk Society: Towards a New Modernity. London: Sage.

Brooks, R. (2007) Young people's extra-curricular activities: Critical social engagement or 'something for the CV'? Journal of Social Policy, 36, 3, 417-434.

Cabinet Office (2014) Community Life Survey: England, 2013/14 Statistical Bulletin. https://www.gov.uk/government/uploads/system/uploads/attachment data/file /335013/Community_Life_Survey_2013-14_Bulletin.pdf

Crary, J. (2014) 24/7: Late Capitalism and the Ends of Sleep. London: Verso.

Curtis, A. (2015) Volunteering in the Downturn. London: Institute for Volunteering Research.

Davies, W. (2014a) The Limits of Neoliberalism: Authority, Sovereignty and the Logic of Competition. London: Sage.

Davies, W. (2014b) Governing through unhappiness. http://potlatch.typepad .com/weblog/2014/12/governing-through-unhappiness.html

de Tocqueville, A. (1862) Democracy in America, New Edition. London: Longman, Green, Longman, and Roberts.

Dean, J. (2014a) How structural factors promote instrumental motivations within youth volunteering: A qualitative analysis of volunteer brokerage. Voluntary Sector Review, 5, 2, 231-247.

Dean, J. (2014b) Recruiting young volunteers in an area of selective education: A qualitative case study. British Journal of Sociology of Education, DOI: 10.1080/01425692.2014.973016.

Delanty, G. (2000) Modernity and Postmodernity. London: Sage.

Douthwaite, R. (1996) Short Circuit: Strengthening Local Economics for Security in an Unstable World. Dartington: Green Books.

Dowling, E. and Harvie, D. (2014) Harnessing the social: State, crisis, and (big) society. Sociology, 48, 5, 869-886.

Edwards, M. (2008) Just Another Emperor? The Myths and Realities of Philanthrocapitalism. London/New York: The Young Foundation/Demos.

Eikenberry, A. (2009) Refusing the market: A democratic discourse for voluntary and nonprofit organizations. Nonprofit and Voluntary Sector Quarterly, 38, 4, 582 596.

Eliasoph, N. (2011) Making Volunteers: Civic Life after Welfare's End. Oxford: Princeton University Press.

Furedi, F. (2004) Where Have All the Intellectuals Gone? London: Continuum.

Furlong, A. and Cartmel, F. (2007) Young People and Social Change: New Perspectives, Second Edition. Maidenhead: Open University Press.

Giddens, A. (1991) Modernity and Self Identity: Self and Society in the Late Modern Age. Oxford: Polity.

Graeber, D. (2013) Debt: The First 5,000 Years. New York: Melville House Publishing.

Groys, B. (2010) The Communist Postscript. London: Verso.

Hall, S. (2011) The neo-liberal revolution. Cultural Studies, 25, 6, 705-728.

Handy, F., Cnann, R., Hustinx, L., Kang C., Brudney, J., Haski-Leventhal, D., Holmes, K., Meijs, L., Pessi, A.B., Ranade, B., Yamauchi, N. and Zrinscak, S. (2010) A cross cultural examination of student volunteering: is it all about resume building? Nonprofit and Voluntary Sector Quarterly, 39, 3, 498-523.

Hancox, D. (2013) The Village Against the World. London: Verso.

Harvey, D. (2011) The Enigma of Capital and the Crises of Capitalism. London: Profile Books.

Hayek, F. (1944) The Road to Serfdom. London: Routledge. 
Hirschman, A. (1982) Shifting Involvement: Private Interest and Public Action. Princeton: Princeton University Press.

Holdsworth, C., and Brewis, G. (2013) Volunteering, choice and control: a case study of higher education student volunteering. Journal of Youth Studies, 17, 2, 204-219

Hustinx, L. (2001) Individualization and new styles of youth volunteering: An empirical exploration. Voluntary Action, 3, 2, 57-77.

Hustinx, L. and Lammertyn, F. (2003) Collective and Reflexive Styles of Volunteering: A Sociological Modernization Perspective. Voluntas, 14, 2, 167-187.

Hustinx, L. and Meijs, L. (2011) Re-embedding volunteerism: in search of a new collective ground. Voluntary Sector Review, 2, 1, 5-21.

Judt, T. (2010) III Fares the Land. London: Penguin.

Kendall, J. (2005) The third sector and the policy process in the UK: ingredients in a hyper-active horizontal policy environment. http://eprints.Ise.ac.uk/29013/1/5TSEP.pdf

Kropotkin, P. (1914) Mutual Aid: A Factor of Evolution. London: Porter Sergeant.

Kunkel, B. (2014) Utopia or Bust: A Guide to the Present Crisis. London: Verso.

Lawler, S. (2005) Introduction: Class, Culture and Identity, Sociology, 39, 5, 797-806.

Lawler, S. (2008) Identity: Sociological Perspectives. London: Polity.

NCIA (2015) Fight or Fright? Voluntary Services in 2015. National Coalition for Independent Action. http://www.independentaction.net/wpcontent/uploads/2015/02/NCIA-Inquiry-summary-report-final.pdf

Nickel, P. and Eikenberry, A. (2009) A Critique of the Discourse of Marketized Philanthropy. American Behavioral Scientist, 52, 7, 974-989.

Nickel, P., and Eikenberry, A. (2013) Gastrophilanthropy: Utopian aspiration and aspirational consumption as political retreat. Reconstruction, 12, 4.

Piketty, T. (2014) Capital in the Twenty-First Century. London: Harvard University Press.

Planty, M., Bozick, R., and Regnier, M. (2006) Helping because you have to or helping because you want to? Sustaining participation in service work from adolescence through young adulthood. Youth \& Society, 38, 2, 177-202.

Rochester, C. (2013) Rediscovering Voluntary Action: The Beat of a Different Drum. Basingstoke: Palgrave.

Rochester, C. (2015) Critical thinking about voluntary action and its history. http://www.vahs.org.uk/2015/02/critical-thinking-about-voluntary-action-and-itshistory

Sandel, M. (2013) What Money Can't Buy: The Moral Limits of Markets. London: Penguin.

Sennett, R. (1998) The Corrosion of Character. New York: W.W. Norton \& Company.

Sheard, J. (1995) From Lady Bountiful to active citizen: volunteering and the voluntary sector, In: J. Davis Smith, C. Rochester and R. Hedley, An Introduction to the Voluntary Sector. London: Routledge. pp. 114-27.

Simmel, G. (2011) The Philosophy of Money. Abingdon: Routledge.

Stiglitz, J. (2013) The Price of Inequality. London: Penguin.

Tönnies, F. (1955) Gemeinschaft und Gesellschaft. London: Routledge.

Warburton, J. and Smith, J. (2003) Out of the generosity of your heart: Are we creating active citizens through compulsory volunteer programmes for young people in Australia? Social Policy \& Administration, 37, 3, 772-786.

Wilkinson, R. and Picket, K. (2010) The Spirit Level: Why Equality is Better for Everyone. London: Penguin.

Wilson, J. and Musick, M. (2000) The effects of volunteering on the volunteer. Law and Contemporary Problems, 62, 4, 141-168. 